\title{
Evaluation of japonica rice (Oryza sativa L.) varieties and their improvement in terms of stability, yield and cooking quality by pure-line selection in Thailand
}

\author{
Pawat Nakwilai $^{\mathrm{a}}$, Sulaiman Cheabu ${ }^{\mathrm{c}}$, Possawat Narumon ${ }^{\mathrm{a}}$, Chatree Saensuk ${ }^{\mathrm{b}}$, Siwaret Arikit ${ }^{\mathrm{a}, \mathrm{b}}$, \\ Chanate Malumpong ${ }^{\mathrm{a}, \mathrm{b}, *}$ \\ a Department of Agronomy, Faculty of Agriculture at Kamphaeng Saen, Kasetsart University, \\ Nakhon Pathom 73140 Thailand \\ ${ }^{\mathrm{b}}$ Rice Science Center \& Rice Gene Discovery Unit, Kasetsart University, Nakhon Pathom 73140 Thailand \\ c Faculty of Agriculture, Princess of Naradhiwas University, Narathiwat 96000 Thailand
}

*Corresponding author, e-mail: agrcnm@ku.ac.th

Received 3 Aug 2019

Accepted 3 Apr 2020

\begin{abstract}
Many companies in Thailand have encouraged farmers, especially those in the northern regions, to cultivate DOA1 and DOA2 japonica rice varieties. Recently, the agronomic traits of DOA1 and DOA2 were altered, affecting yield and cooking quality. Thus, the objectives of this study were to evaluate the agronomic traits and cooking quality of DOA1 and DOA2 and those of exotic japonica varieties in different locations, including the Kamphaeng Saen and Phan districts (WS16). DOA2 was improved by pure-line selection. The results showed that the Phan district was better suited to grow japonica varieties than the Kamphaeng Saen district and that DOA2 produced high grain yields in both locations. Furthermore, DOA2 was selected by the pure-line method in four generations, after which five candidate lines, Tana1 to Tana5, were selected for yield trials. The results of yield trials in three seasons (WS17, DS17/18, WS18) confirmed that Tana1 showed high performance in terms of its agronomic traits and grain yield. Moreover, the cooking quality of Tana1 was the same as that of DOA2. When the genotypes of the five candidate lines were compared with those of DOA1, DOA2, Akitakomachi, Sasanishiki and Koshihikari, it was found that Tana1 slightly differed from DOA2. In addition, the japonica varieties introduced from Japan were also different from DOA1 and DOA2. These results suggest that the genotype of DOA2 changed greatly from that of the original variety, Akitakomachi. Thus, pure-line selection can slightly alter the genetics of DOA2, improve agronomic traits and increase grain yields.
\end{abstract}

KEYWORDS: japonica rice, pure-line selection, agronomic traits, cooking quality

\section{INTRODUCTION}

The market demand for Japanese rice is relatively high in Thailand because chains and branches of Japanese restaurants have expanded throughout the country as a whole. In fact, restaurant chains from Japan have increasingly invested in Thailand to open Japanese restaurants at a growth rate of 10$15 \%$ per year. As a result, Thailand is the fifth in the world in terms of the number of Japanese restaurants [1]. In 2014, thirteen private entrepreneurs in Thailand encouraged farmers to cultivate japonica rice via contract farming systems. Ten of these entrepreneurs were members of the Association of Japanese Rice Producers in Thailand. The total area of cultivated paddy fields under the association was approximately 80000 rais (12800 ha), which involved 6000 contract farmers. The total paddy yield was approximately 60000 tons, with a $750 \mathrm{~kg} / \mathrm{rai}$ average yield [2]. Chiang Rai, the northern province in Thailand, has become a major production base for japonica rice because of its climate and locally developed strains of japonica varieties that have qualities similar to those grown in Japan [3].

Japanese people prefer cooked japonica rice for its sticky and chewy texture and dislike rice with a dry and crisp texture. In fact, strong stickiness is one of the most important features [4-6]. Thus, high eating quality is one of the major reasons why Koshihikari $(\mathrm{KH})$ japonica rice is preferred by Japanese consumers [7]. KH, a premium short-grain rice cultivar, was first bred in Japan in 1956. It became the cultivar with the largest cultivation area in 1979 [7]. The eating quality of $\mathrm{KH}$ is superior to that of Nipponbare, a standard rice, and the appearance, scent, flavor, stickiness and overall evaluation 
of the former are better. Moreover, cooked $\mathrm{KH}$ rice is much softer than Nipponbare rice [5]. In addition, the three top-ranked cultivars after $\mathrm{KH}$ are Hitomebore, Hinohikari and Akitakomachi (AK). Among the other cultivars, Sasanishiki (SN), which is soft but not as sticky, is preferred for box lunches and sushi and is in demand by the food industry and consumers [8].

Experiments with japonica rice in Thailand have been conducted for more than 50 years by researchers at the Chiang Rai Rice Research Center (CRC), Department of Rice. In 1964, the CRC introduced japonica rice germplasm from Japan for experiments involving different rice varieties. There are many varieties such as $\mathrm{AK}, \mathrm{KH}$, Norin and $\mathrm{SN}$ [9]. The CRC has continuously experimented to cultivate Japanese rice at research stations and in farmlands, especially in northern provinces such as Chiang Rai, Chiang Mai and Lamphun [10]. In 1995, the Department of Agriculture (DOA) confirmed that two japonica rice varieties, SN and AK, could produce high yields and good cooking quality in northern Thailand. Afterward, these varieties, including DOA1 (SN) and DOA2 (AK), were registered as certified varieties and were recommended for expansion and cultivation [9]. The DOA1 and DOA2 varieties have a quality similar to that of $\mathrm{KH}$ and were the first varieties sold as consumer grade in Japanese markets [10]. Moreover, they are suitable for growth in areas where the average temperature is approximately $18-25^{\circ} \mathrm{C}$, and their resistance to hot weather is stronger than that of other japonica rice varieties [3]. These two varieties can grow during both wet season (Jul-Oct) and dry season (Jan-May) in northern provinces in Thailand. The yields of DOA2 and DOA1 from the CRI experiment were $5168 \mathrm{~kg} / \mathrm{ha}$ and $4637 \mathrm{~kg} / \mathrm{ha}$, respectively [3].

Global warming increased the average minimum temperature by approximately $1.1^{\circ} \mathrm{C}$ from 1966 to 2001 [11], and the temperature during the ripening period has also increased by $1.1^{\circ} \mathrm{C}$ above that in previous years [12]. Therefore, a heat-induced decline in the quality of japonica rice has been observed in many prefectures in Japan $[12,13]$. Thus, conditions such as high temperature and low humidity tend to prevent this rice from achieving the same quality as it does in Japan $[14,15]$. In Thailand, the annual mean temperature is projected to rise by $4.8^{\circ} \mathrm{C}$ by 2100 [16]. Thailand experiences an average daytime temperature of up to $40^{\circ} \mathrm{C}$, especially during the month of Apr [17]. These temperatures may severely affect the yield and grain quality of japonica rice in Thailand. Moreover, at present, the DOA1 and DOA2 plants growing on farmland in Chiang Rai were off-type approximately $13 \%$ and $4 \%$, respectively [18]. Moreover, comparisons of genetic backgrounds by ddRAD sequencing analysis of these cultivars showed that they had already changed from their original cultivars (SN and AK). Thus, after 25 years, the DOA1 and DOA2 varieties were not completely SN and AK, respectively. Pure-line selection involves three steps through which a variety can evolve: the selection of individual plants from a crop comprising a local variety or mixed populations, the visual evaluation of individual plant progeny and the establishment of yield trials [19].

This study had two objectives. The first was to evaluate the yield and cooking quality of DOA1 and DOA2 and compare them with those of the other four japonica varieties derived from Japan at two locations: the Phan district in Chiang Rai (the main area of japonica rice production) and the Kamphaeng Saen (KPS) district in Nakhon Pathom (central part of Thailand). The second was to improve the uniformity, yield and cooking quality of DOA2 by pure-line selection and to analyze the genetic relationship by the genotype-by-sequencing (GBS) method to compare the newly selected lines with the original DOA2.

\section{MATERIALS AND METHODS}

\section{Experiment 1: Evaluation of japonica varieties}

\section{Plant materials and growth conditions}

This experiment was conducted in the wet season from Jun-Oct 2016 at two locations: Tana Grain Polish, Ltd., Phan district, Chiang Rai province $\left(19^{\circ} 35^{\prime} 09.4^{\prime \prime} \mathrm{N}, 99^{\circ} 44^{\prime} 42.7^{\prime \prime} \mathrm{E}, 413 \mathrm{~m}\right.$ above sea level) and the rice research field at Kasetsart University, Kamphaeng Saen district, Nakhon Pathom province $\left(14^{\circ} 02^{\prime} 13.5^{\prime \prime} \mathrm{N}, 99^{\circ} 57^{\prime} 45.0^{\prime \prime} \mathrm{E}, 10 \mathrm{~m}\right.$ above sea). The four japonica varieties introduced from Japan included Koshihikari (KH), Akitakomachi (AK), Sasanishiki (SN) and Saino Kagayaki (SK). DOA1 and DOA2 were derived from foundation seed of the CRC; these varieties were seeded in the field nursery. After 30 days, the rice seedlings were transplanted to a research paddy field set up in a randomized complete block design (RCBD) with three replications. The plot size in each treatment was as $1 \times 4 \mathrm{~m}$ (4 rows) with a spacing of $25 \times 25 \mathrm{~cm}$. The soil nutrients and other properties were analyzed by the Department of Soil Science, Faculty of Agriculture at Kamphaeng Saen, Kasetsart University (Table S1). Additionally, 18-22-0 
fertilizer was applied at a rate of $87.5 \mathrm{~g} /$ subplot at 15 days after planting, and 46-0-0 fertilizer was applied at $25 \mathrm{~g} /$ subplot at the booting stage (65 days). Other management practices were in accordance with conventional high-yield cultivation approaches [3]. Weather data, including air temperature, relative humidity and the amount of rain in the field, were measured every $10 \mathrm{~min}$ from planting until harvest by a data logger (WatchDog 2700 Series Micro Stations, Spectrum Technologies, Inc., USA).

Plants in the two middle rows of each subplot from each replicate at both locations were harvested to determine their agronomic traits including days until flowering (DF), plant height $(\mathrm{PH})$, tillers/plant $(\mathrm{T} / \mathrm{P})$, panicles/plant $(\mathrm{P} / \mathrm{P})$, panicle length (PL), seed set (SS), 100-grain weight (GW) and grain yield/plant $(\mathrm{Gy} / \mathrm{Pl})$. Furthermore, the cooking quality traits included grain size (GS), grain elongation (GE), an alkaline test (AT) and amylose content (AC). These traits were evaluated only at the Phan district location.

\section{Experiment 2: Pure-line selection of DOA2}

\section{Plant materials and growth conditions}

The DOA2 seed germplasm was collected from three sources: the CRC; Department of Rice, Tana Grain Co. Ltd. and the Rice Science Center; Kasetsart University. AK, SN and $\mathrm{KH}$ were used as control varieties in each generation of the pure-line procedure. The rice management practices were the same as those in Experiment 1.

\section{Pure-line selection scheme}

The pure-line selection scheme is shown in Fig. S1. In the first season, sixty DOA2 seeds from each source (total of one hundred and eighty seeds) were grown at the rice research field of Tana Grain Co. Ltd., Phan district, Chiang Rai province from Mar-Jun 2016. The seeds were grown in a nursery field. After 30 days, the seedlings were transplanted at a spacing of $30 \times 30 \mathrm{~cm}$. The rice plants that had agronomic traits closest to those of DOA2 or AK and that yielded greater than $85 \%$ seed set on the panicles were selected and harvested separately for growth in the next season. In the second to third season (Jul 2016-May 2017), the selected panicles were grown as panicles/rows at a spacing of $25 \times 25 \mathrm{~cm}$. The off-type plants in each row were removed, and selected plants were harvested individually. Additionally, in the fourth season (wet season; May-Sep 2017) and the fifth season (dry season; Dec 2017-Apr 2018), the remaining progeny were planted for preliminary yield trials, and inferior progeny and those with low yield were rejected. Finally, in the sixth season (wet season; Jul-Oct 2018), the five candidate lines derived from previous selections were grown for yield trials with DOA1, DOA2, AK, SN and $\mathrm{KH}$ at the research field of Tana Grain Co. Ltd., Chiang Rai province. The experiment for the yield trial was conducted as a RCBD with three replications. The plot size for each treatment was $2.5 \times 2.5 \mathrm{~m}\left(6.25 \mathrm{~m}^{2}\right)$ with a spacing of $25 \times 25 \mathrm{~cm}$. The agronomic trait, cooking quality trait (only in the sixth season) and sensory test (only in the sixth season) data were collected. The weather data, including the air temperature, relative humidity and amount of rain in the field, were measured every $10 \mathrm{~min}$ in each season from planting until harvest by a data logger (WatchDog 2000 Series Micro Stations, Spectrum Technologies, Inc., USA).

\section{Agronomic traits}

Grain yield/plot (Gy/Po) was determined by per harvested area of $6.25 \mathrm{~m}^{2}$. The grain yield moisture was adjusted to $14 \%$. The agronomic traits (i.e., $\mathrm{DF}, \mathrm{PH}, \mathrm{PL}$ and $\mathrm{T} / \mathrm{P}$ ) and the components of grain yield (i.e., $\mathrm{P} / \mathrm{P}$, SS and GW) were measured in plants within $4 \mathrm{~m}^{2}$ (excluding guard rows). Fifty percent of representative plants were randomly selected to calculate the $\mathrm{T} / \mathrm{P}$ and $\mathrm{P} / \mathrm{P}$. After threshing, the grains were weighed to obtain the 100-grain weight, and this step was repeated three times. SS was defined as the number of filled grains per total number of spikelets.

\section{Cooking quality traits}

Grain size (GS): The grain width and grain length of both paddy rice and milled rice in the validation experiment were measured using ten seeds with three replications. A two-decimal-point digital Vernier caliper was used.

Alkaline test (AT): The alkalinity was determined using an alkali digestion test [20]. Three replicates in each treatment of ten whole-milled grains without cracks were selected and placed in a Petri dish. Ten milliliters of $1.7 \%(0.3035 \mathrm{M})$ $\mathrm{KOH}$ solution was then added. The samples were arranged to provide enough space between kernels to allow for spreading. The Petri dishes were subsequently covered and incubated for $24 \mathrm{~h}$ at room temperature (approximately $32^{\circ} \mathrm{C}$ ). The starchy endosperm was rated visually based on a seven-point numerical spreading scale in accordance with the 
standard evaluation system for rice [21]. According to the AT score, the GT of rice grains could be classified into four groups: high (1-2), high-intermediate (3), intermediate (4-5) and low (6-7) [22].

Amylose content (AC): One hundred milligrams of each milled rice was added to $1 \mathrm{ml}$ of ethanol (95\%) and $9 \mathrm{ml}$ of $1 \mathrm{~N} \mathrm{NaOH}$. Each sample was heated for $10 \mathrm{~min}$ in a boiling water bath to gelatinize the starch. The samples were then cooled and transferred to a $100 \mathrm{ml}$ volumetric flask. Five milliliters of starch solution and $1 \mathrm{ml}$ of $1 \mathrm{~N}$ acetic acid were then added. Two milliliters of iodine solution $(0.2 \%$ resublimed iodine in $2 \%$ potassium iodide) was added, and the volume was brought to $100 \mathrm{ml}$. The flask was subsequently shaken and allowed to stand for $20 \mathrm{~min}$. The absorbance at $620 \mathrm{~nm}$ was measured against the blank using ultraspectrophotometer (Spectramax model Plus 384 components, USA); and a calibration standard amylose curve by plotting absorbance was prepared. The total amylose content of each sample was determined via a previously calibrated standard amylose curve [23].

Grain elongation ratio (GE): Ten whole-milled grains and ten cooked grains were sampled with three replications. The grains were measured by a digital Vernier caliper. The grain elongation ratio was subsequently calculated by means of ten wholemilled grain lengths divided by the mean of ten cooked grain lengths.

\section{Evaluation of sensory qualities of cooked rice}

The rice cooking procedure was in accordance with the standard method for the sensory evaluation of rice cooking and eating qualities at Tana Grain Co. Ltd. Whole-milled rice samples (500 g, 14\% moisture content) were washed three times with distilled water. The distilled water was added to the rice samples to give an optimum rice:water weight ratio (1.0:1.4). The rice was cooked using the preset cooking setting of a rice cooker (Sharp model KS-ZT18, Thailand). Before cooking, the rice samples were soaked at room temperature for $30 \mathrm{~min}$ and then boiled for $35 \mathrm{~min}$; this was followed by a 15 min holding period at the warming setting. Seven panelists (two women and five men) who had been well trained in the principles and concepts of descriptive sensory analysis for at least three years participated in the evaluation of sensory qualities. The sensory items included the smell (score 1-5), appearance (score 1-5), stickiness (score 1-5), softness (score 1-5) and taste (score 1-5). The smell was evaluated by sniffing the aroma of cooked rice before putting it into the mouth. The appearance (color, glossiness and integrity) was evaluated by the surface characteristics of the cooked rice, and the stickiness was evaluated during the chewing stage as the degree to which the sample adhered to the molar teeth. The softness was assessed by compressing the sample between molars and evaluating the force required to bite through the sample during the first few bites. The stickiness, elasticity and hardness could be evaluated at the same time. Taste was a comprehensive evaluation of sweetness and fragrance and included the purity and durability of taste. A comprehensive assessment was scored based on the above factors. Using a relative scale, the panelists gave a score for each attribute compared with the reference sample attributes, and the overall quality was the sum of the scores for all the attributes. The total scores were then analyzed via $F$-tests as part of a CRD experiment.

\section{Phylogenetic analysis based on GBS}

Genomic DNA was prepared from a single plant of each candidate line and controlled varieties. DNA from leaves was isolated according to the DNeasy Plant Mini Kit (Qiagen) protocol. The DNA quantity was tested by a NanoDrop 8000 , and the concentration exceeded $50 \mathrm{ng} / \mu \mathrm{l}$. The DNA was then sequenced on an Illumina HiSeq $X$ by Novogene AIT, Singapore. The Bowtie 2 program was subsequently used to align the nucleotides [24], and the GATK program was used to analyze single-nucleotide polymorphisms (SNPs) in each sample [25]. Finally, the nucleotide sequences from the candidate lines and controlled varieties were used to construct a phylogenetic tree using the MEGA X program (Molecular Evolutionary Genetics Analysis version 10.0, www. megasoftware.net).

\section{Statistical Analysis}

All the data were analyzed using the $\mathrm{R}$ program version 3.6.1 [26] to test the significance of the results in terms of agronomic traits and cooking quality. The means were separated using Tukey's Least Significant Difference test at $p<0.05$. If there was no significant difference among the experiments for a given parameter, then the values from all of the experiments for that parameter were used to obtain the mean and standard error. In addition, the AMMI model was used to analyze the $\mathrm{G} \times \mathrm{E}$ interactions [27]. 


\section{RESULTS}

\section{Experiment 1}

Weather data: The daytime temperatures (6.0018.00 h) from Jun-Oct 2016 in KPS and Phan were $33.1^{\circ} \mathrm{C}$ and $31.0^{\circ} \mathrm{C}$, respectively, and the nighttime temperatures (18.00-6.00 h) in KPS and Phan were $27.6^{\circ} \mathrm{C}$ and $25.5^{\circ} \mathrm{C}$, respectively. Thus, the air temperature in KPS was higher than that in Phan during both day and night by approximately $2.0^{\circ} \mathrm{C}$ (Table S2). The daytime relative humidity levels in KPS were slightly different from those in Phan (57.9\% RH in KPS and 56.2\% RH in Phan). However, the nighttime relative humidity in Phan was higher than that in KPS $(89.7 \% \mathrm{RH}$ in KPS and 93.1\% RH in Phan) (Table S2). The average rainfall during five months in this experiment in KPS was lower than that in Phan (141.64 $\mathrm{mm}$ in KPS and $304.06 \mathrm{~mm}$ in Phan) (Table S2).

\section{Yield and agronomic traits}

Table 1 summarizes the computed $F$-values for the differences in yield and agronomic traits. The yield and agronomic traits were significantly different between the two locations except tillers/plant and panicles/plant. In addition, the $F$-values of the yield and agronomic traits were also different among varieties in each location.

The yield and agronomics traits of all varieties in Phan were higher than those in KPS, especially the Gy/Pl, DF, PH and SS. DOA2 in Phan and KPS presented the highest Gy/Pl (64.6 g and $41.5 \mathrm{~g}$, respectively) and SS (95.4\% and 82.4\%, respectively) (Table 1). On the other hand, the lowest yield in Phan occurred for AK while the lowest yield in KPS occurred for SK, which produced yields of $24.2 \mathrm{~g}$ and $22.7 \mathrm{~g}$, respectively (Table 1 ).

The mean DF of the six japonica varieties in Phan was 78 days while it was 69 days in KPS (Table 1). Thus, the DF of all varieties except SN and DOA2 in Phan was greater than that in KPS. The greatest difference in DF between Phan and KPS occurred for SK (difference of 19 days) while the DF for $\mathrm{SN}$ was not different between the two locations.

The PH showed the same result as the days until flowering. The plant heights of the six japonica varieties in Phan $(86.6 \mathrm{~cm})$ were higher than those in KPS $(73.7 \mathrm{~cm})$. The shortest variety was SK in both Phan $(71.9 \mathrm{~cm})$ and KPS $(54.9 \mathrm{~cm})$ while the tallest varieties in both locations were DOA1 (97.3 $\mathrm{cm}$ in Phan and $89.2 \mathrm{~cm}$ in KPS) and DOA2 (90.6 cm in Phan and $88.4 \mathrm{~cm}$ in KPS) (Table 1).

\section{Grain quality}

The grain quality of the six japonica varieties was evaluated only in Phan. The GS of paddy grain (2.6-3.1 $\mathrm{mm}$ in width and 7.1-7.5 $\mathrm{mm}$ in length), milled grain $(2.5-3.0 \mathrm{~mm}$ in width and $4.7-5.0 \mathrm{~mm}$ in length) and the AC (17.8-22.3\%) among the six varieties were significant (Table 2). On the other hand, the $\mathrm{AC}$ of $\mathrm{KH}$ was the lowest (17.8\%) while that of the other varieties was not significant (21.1$22.3 \%)$. In addition, the GE $(1.8-2.0 \mathrm{~mm})$ and AT (score 5-6) were not significant among the six varieties (Table 2).

Thus, in Experiment 1, the agronomic traits and yield in Phan, Chiang Rai province, which is the main japonica rice growing area in Thailand, were good compared with those in KPS. In addition, when the grain quality of the six varieties in Phan were compared, the results showed that there was no significant difference across all varieties, and these were compared with the standards of japonica rice [28]. Moreover, DOA2 produced the highest yields both in the Phan and KPS locations, especially in Phan. Thus, DOA2 was used for the pure-line selection in Experiment 2 to increase the uniformity and yield.

\section{Experiment 2}

Sixty seeds from each germplasm source (total of one hundred and eighty seeds) were grown at the rice research field of Tana Grain Co. Ltd., Phan, Chiang Rai province, from Mar-Jun 2016. Five candidate lines were ultimately derived after 4thgeneration pure-line selection; plants from these lines were subsequently grown as part of yield trials together with DOA1, DOA2, AK, SN and $\mathrm{KH}$ in the fourth season (WS17; May-Sept 2017), fifth season (DS17/18; Dec 2017-Apr 2018) and sixth season (WS18; Jul-Nov 2018).

\section{Weather data}

The weather data during the three seasons of the yield trials are shown in Table S3. The mean daytime and nighttime temperatures during the growing season in WS17 $\left(28.70 / 25.07^{\circ} \mathrm{C}\right)$ and WS18 $\left(28.06 / 24.17^{\circ} \mathrm{C}\right)$ were higher than those in $\mathrm{DS} 17 / 18\left(25.80 / 20.45^{\circ} \mathrm{C}\right)$. The mean relative humidity in the daytime of WS17, DS17/18 and WS18 was $79.43,73.74$ and $81.68 \% \mathrm{RH}$, respectively while the relative humidity at night was 91.31, 90.47 and $93.55 \% \mathrm{RH}$, respectively. In addition, the average rainfall was highest in WS17 $(304.9 \mathrm{~mm})$, followed by WS18 $(198.2 \mathrm{~mm})$ and 
Table 1 The agronomic traits of 6 japonica varieties between KPS and Phan district in the WS16.

\begin{tabular}{|c|c|c|c|c|c|c|c|c|}
\hline \multirow{2}{*}{ Variety } & \multicolumn{2}{|c|}{ DF (day) } & \multicolumn{2}{|c|}{$\mathrm{PH}(\mathrm{cm})$} & \multicolumn{2}{|c|}{$\mathrm{T} / \mathrm{P}$} & \multicolumn{2}{|c|}{$\mathrm{P} / \mathrm{P}$} \\
\hline & KPS & Phan & KPS & Phan & KPS & Phan & KPS & Phan \\
\hline $\begin{array}{l}\text { SK } \\
\text { KH } \\
\text { SN } \\
\text { AK } \\
\text { DOA1 } \\
\text { DOA2 }\end{array}$ & $\begin{array}{l}66^{\mathrm{eB}} \\
68^{\mathrm{cB}} \\
72^{\mathrm{bA}} \\
67^{\mathrm{cdB}} \\
66^{\mathrm{deB}} \\
76^{\mathrm{aA}}\end{array}$ & $\begin{array}{l}85^{\mathrm{aA}} \\
85^{\mathrm{aA}} \\
70^{\mathrm{bA}} \\
85^{\mathrm{aB}} \\
70^{\mathrm{bA}} \\
70^{\mathrm{bB}}\end{array}$ & $\begin{array}{l}54.9^{\mathrm{dB}} \\
65.2^{\mathrm{cB}} \\
76.5^{\mathrm{bB}} \\
67.9^{\mathrm{cB}} \\
89.2^{\mathrm{aB}} \\
88.4^{\mathrm{aB}}\end{array}$ & $\begin{array}{l}71.9^{\mathrm{dA}} \\
81.4^{\mathrm{bcdA}} \\
80.8^{\mathrm{bcdA}} \\
74.6^{\mathrm{cdA}} \\
97.3^{\mathrm{aA}} \\
90.6^{\mathrm{abA}}\end{array}$ & $\begin{array}{l}18^{\mathrm{bcA}} \\
18^{\mathrm{bcA}} \\
17^{\mathrm{cA}} \\
15^{\mathrm{dA}} \\
17^{\mathrm{cA}} \\
20^{\mathrm{aA}}\end{array}$ & $\begin{array}{l}18^{\mathrm{bA}} \\
18^{\mathrm{bA}} \\
18^{\mathrm{bA}} \\
15^{\mathrm{cA}} \\
17^{\mathrm{bcA}} \\
20^{\mathrm{aA}}\end{array}$ & $\begin{array}{l}18^{\mathrm{abA}} \\
19^{\mathrm{aA}} \\
18^{\mathrm{abA}} \\
18^{\mathrm{abA}} \\
15^{\mathrm{cB}} \\
13^{\mathrm{dB}}\end{array}$ & $\begin{array}{l}17^{\mathrm{bA}} \\
17^{\mathrm{bB}} \\
16^{\mathrm{cB}} \\
14^{\mathrm{dB}} \\
17^{\mathrm{bA}} \\
19^{\mathrm{aA}}\end{array}$ \\
\hline $\begin{array}{l}\text { Mean } \\
F \text {-test }\end{array}$ & $\begin{array}{l}69 \\
* *\end{array}$ & 78 & $\begin{array}{c}73.7 \\
* *\end{array}$ & 86.6 & 18 & 18 & 18 & 17 \\
\hline$\% \mathrm{CV}$ & 1.07 & 0.85 & 4.04 & 7.74 & 1.57 & 2.64 & 13.4 & 3.00 \\
\hline \multirow{2}{*}{ Variety } & \multicolumn{2}{|c|}{$\mathrm{PL}(\mathrm{cm})$} & \multicolumn{2}{|c|}{ SS (\%) } & \multicolumn{2}{|c|}{ GW (g) } & \multicolumn{2}{|c|}{$\mathrm{Gy} / \mathrm{Pl}(\mathrm{g})$} \\
\hline & KPS & Phan & KPS & Phan & KPS & Phan & KPS & Phan \\
\hline $\begin{array}{l}\text { SK } \\
\text { KH } \\
\text { SN } \\
\text { AK } \\
\text { DOA1 } \\
\text { DOA2 }\end{array}$ & $\begin{array}{l}14.57^{\mathrm{dB}} \\
14.82^{\mathrm{dB}} \\
17.00^{\mathrm{cB}} \\
16.05^{\mathrm{cB}} \\
20.33^{\mathrm{bB}} \\
19.94^{\mathrm{bB}}\end{array}$ & $\begin{array}{l}34.3^{\mathrm{aA}} \\
21.0^{\mathrm{dA}} \\
25.2^{\mathrm{bA}} \\
20.2^{\mathrm{dA}} \\
23.6^{\mathrm{cA}} \\
26.5^{\mathrm{bA}}\end{array}$ & $\begin{array}{l}60.5^{\mathrm{dB}} \\
66.3^{\mathrm{bB}} \\
65.0^{\mathrm{bcB}} \\
64.6^{\mathrm{cdB}} \\
82.0^{\mathrm{aB}} \\
82.4^{\mathrm{aB}}\end{array}$ & $\begin{array}{l}94.7^{\mathrm{abA}} \\
94.3^{\mathrm{abA}} \\
89.2^{\mathrm{cA}} \\
93.7^{\mathrm{abA}} \\
91.2^{\mathrm{bA}} \\
95.4^{\mathrm{aA}}\end{array}$ & $\begin{array}{l}2.57^{\mathrm{bcB}} \\
2.52^{\mathrm{cB}} \\
2.43^{\mathrm{dB}} \\
2.62^{\mathrm{bB}} \\
2.22^{\mathrm{eB}} \\
2.97^{\mathrm{aA}}\end{array}$ & $\begin{array}{l}2.69^{\mathrm{cA}} \\
2.78^{\mathrm{bA}} \\
2.61^{\mathrm{dA}} \\
2.73^{\mathrm{bcA}} \\
3.05^{\mathrm{aA}} \\
2.98^{\mathrm{aA}}\end{array}$ & $\begin{array}{l}22.7^{\mathrm{eB}} \\
25.6^{\mathrm{dB}} \\
35.9^{\mathrm{bcA}} \\
33.9^{\mathrm{cA}} \\
33.1^{\mathrm{cB}} \\
41.5^{\mathrm{aB}}\end{array}$ & $\begin{array}{l}26.4^{\mathrm{dA}} \\
33.7^{\mathrm{dA}} \\
33.8^{\mathrm{cB}} \\
24.2^{\mathrm{dB}} \\
56.5^{\mathrm{bA}} \\
64.6^{\mathrm{aA}}\end{array}$ \\
\hline $\begin{array}{l}\text { Mean } \\
F \text {-test }\end{array}$ & 18.60 & 25.3 & 70.1 & 93.1 & 2.55 & 2.80 & 32.1 & 45.5 \\
\hline$\% \mathrm{CV}$ & 3.72 & 2.87 & 4.21 & 2.26 & 1.57 & 1.51 & 3.54 & 4.10 \\
\hline
\end{tabular}

Different small letters in the column (agronomic traits) are significantly different at $p<0.05$. Different capital letters in each row (genotype) between locations are significantly different at $p<0.05$.

Table 2 Grain and cooking quality of 6 japonica varieties in Phan, Chiang Rai province in the WS16.

\begin{tabular}{|c|c|c|c|c|c|c|c|}
\hline \multirow{2}{*}{ Variety } & \multicolumn{2}{|c|}{ Paddy GS (mm) } & \multicolumn{2}{|c|}{ Milled GS (mm) } & \multirow{2}{*}{$\begin{array}{c}\mathrm{GE} \\
(\mathrm{mm})\end{array}$} & \multirow{2}{*}{$\begin{array}{c}\text { AT } \\
\text { (score } 1-6)\end{array}$} & \multirow{2}{*}{$\begin{array}{l}\text { AC } \\
(\%)\end{array}$} \\
\hline & Width & Length & Width & Length & & & \\
\hline SK & $2.9^{\mathrm{b}}$ & $7.3^{c}$ & $2.5^{c}$ & $4.8^{c}$ & 1.9 & 5 & $21.5^{\mathrm{a}}$ \\
\hline $\mathrm{KH}$ & $2.8^{\mathrm{c}}$ & $7.1^{\mathrm{d}}$ & $2.5^{c}$ & $4.7^{\mathrm{d}}$ & 1.9 & 5 & $17.8^{\mathrm{b}}$ \\
\hline SN & $2.6^{\mathrm{c}}$ & $7.1^{\mathrm{d}}$ & $2.5^{c}$ & $4.8^{c}$ & 2.0 & 6 & $22.3^{\mathrm{a}}$ \\
\hline $\mathrm{AK}$ & $2.9^{\mathrm{b}}$ & $7.5^{\mathrm{a}}$ & $2.6^{\mathrm{b}}$ & $5.0^{\mathrm{a}}$ & 1.8 & 5 & $21.1^{\mathrm{a}}$ \\
\hline DOA1 & $2.9^{\mathrm{b}}$ & $7.4^{\mathrm{b}}$ & $3.0^{\mathrm{a}}$ & $4.9^{\mathrm{b}}$ & 1.8 & 5 & $22.2^{\mathrm{a}}$ \\
\hline DOA2 & $3.1^{\mathrm{a}}$ & $7.5^{\mathrm{a}}$ & $3.0^{\mathrm{a}}$ & $4.9^{b}$ & 1.8 & 5 & $21.9^{\mathrm{a}}$ \\
\hline Mean & 2.9 & 7.3 & 2.7 & 4.8 & 1.9 & 5.2 & 21.1 \\
\hline$F$-test & $* *$ & $* *$ & $* *$ & $* *$ & ns & ns & $* *$ \\
\hline$\% \mathrm{CV}$ & 1.02 & 2.09 & 1.04 & 3.05 & 1.05 & 1.11 & 2.69 \\
\hline
\end{tabular}

Different small letters in the column (grain and cooking quality) are significantly different at $p<0.05$.

DS17/18 (62.9 mm).

\section{Yield and agronomic traits}

The yield and agronomic traits of the five candidate lines as well as the controlled varieties in the three seasons are shown in Table 3 . In addition, the plant type, paddy grains and milled grains of these line/varieties are shown in Fig. 1. The yield and agronomic traits were significantly different among the seasons $(p<0.05)$. In addition, except for those of $\mathrm{T} / \mathrm{P}$ and $\mathrm{P} / \mathrm{P}$, the $F$-values of the yield and agronomic traits were also different among the lines/varieties in each season. The mean DF in DS17/18 (90 days) was longer than that of WS17 (72 days) and WS18 (73 days) (Table 3). This finding showed that the air temperature in the DS (winter season) was lower than that in the WS
(Table S3). These results suggest that rice plants in the WS accumulated heat units faster than they did in the DS and that the rice plants changed from the vegetative to reproductive stage earlier in the WS than in the DS. In addition, with respect to the DF among the five candidate lines, the DF values for DOA1 and DOA2 were not significant in WS17 (73-74 days), but there were significant differences in WS18 (74-79 days). However, the DF of AK, SN and $\mathrm{KH}$, which are derived from Japan, was shorter (66-67 days in WS17, 75-83 days in DS17/18 and 66-67 days in WS18) than that of the other lines/varieties (Table 3).

With respect to the $\mathrm{PH}$ of the five candidate lines, the values for DOA1 and DOA2 in the three seasons (89-118 cm in WS17, 101-111 cm in DS17/18 and 104-108 cm in WS18) were greater 
Table 3 The agronomic traits of 5 candidate lines compared with control varieties in Phan, Chiang Rai province in the WS17, DS17/18 and WS18.

\begin{tabular}{|c|c|c|c|c|c|c|c|c|c|c|c|c|c|c|}
\hline Trait & Season & Tana1 & Tana2 & Tana3 & Tana4 & Tana5 & DOA1 & DOA2 & AK & SS & $\mathrm{KH}$ & Mean & $F$-test & $\% \mathrm{CV}$ \\
\hline $\begin{array}{l}\text { DF } \\
\text { (day) }\end{array}$ & $\begin{array}{l}\text { WS17 } \\
\text { DS17/18 } \\
\text { WS18 } \\
\text { Mean }\end{array}$ & $\begin{array}{l}74^{\mathrm{abB}} \\
97^{\mathrm{aA}} \\
74^{\mathrm{bcB}} \\
81.7\end{array}$ & $\begin{array}{l}75^{\mathrm{aB}} \\
96^{\mathrm{aA}} \\
77^{\mathrm{abB}} \\
81.7\end{array}$ & $\begin{array}{l}75^{\mathrm{aB}} \\
95^{\mathrm{aA}} \\
77^{\mathrm{abB}} \\
82.3\end{array}$ & $\begin{array}{l}74^{\mathrm{abB}} \\
96^{\mathrm{aA}} \\
76^{\mathrm{abcB}} \\
82.0\end{array}$ & $\begin{array}{l}75^{\mathrm{aB}} \\
95^{\mathrm{aA}} \\
79^{\mathrm{abcB}} \\
83.0\end{array}$ & $\begin{array}{l}75^{\mathrm{aB}} \\
97^{\mathrm{aA}} \\
76^{\mathrm{abcB}} \\
82.7\end{array}$ & $\begin{array}{l}73^{\mathrm{bB}} \\
95^{\mathrm{aA}} \\
72^{\mathrm{cB}} \\
80.0\end{array}$ & $\begin{array}{l}67^{\mathrm{cB}} \\
77^{\mathrm{cA}} \\
66^{\mathrm{dB}} \\
70.0\end{array}$ & $\begin{array}{l}67^{\mathrm{cB}} \\
83^{\mathrm{bA}} \\
67^{\mathrm{dB}} \\
72.3\end{array}$ & $\begin{array}{l}66^{\mathrm{cB}} \\
75^{\mathrm{cA}} \\
67^{\mathrm{dB}} \\
69.3\end{array}$ & $\begin{array}{l}72 \\
90 \\
73 \\
78.7\end{array}$ & $\begin{array}{l}* * \\
* * \\
* *\end{array}$ & $\begin{array}{l}1.57 \\
2.46 \\
3.56\end{array}$ \\
\hline $\begin{array}{l}\mathrm{PH} \\
(\mathrm{cm})\end{array}$ & $\begin{array}{l}\text { WS17 } \\
\text { DS17/18 } \\
\text { WS18 } \\
\text { Mean }\end{array}$ & $\begin{array}{l}108.5^{\mathrm{aB}} \\
111.4^{\mathrm{aA}} \\
107.0^{\mathrm{aB}} \\
108.9^{4}\end{array}$ & $\begin{array}{l}109.5^{\mathrm{aA}} \\
106.4^{\mathrm{bB}} \\
107.8^{\mathrm{aB}} \\
107.9^{2}\end{array}$ & $\begin{array}{l}117.7^{\mathrm{aA}} \\
104.3^{\mathrm{bcC}} \\
109.4^{\mathrm{aB}} \\
110.5\end{array}$ & $\begin{array}{l}102.9^{\mathrm{bB}} \\
102.8^{\mathrm{bcB}} \\
108.9^{\mathrm{aA}} \\
104.9^{4}\end{array}$ & $\begin{array}{l}101.4^{\mathrm{bB}} \\
102.7^{\mathrm{bcB}} \\
104.1^{\mathrm{aA}} \\
102.7^{2}\end{array}$ & $\begin{array}{c}89.3^{\mathrm{dB}} \\
103.3^{\mathrm{bcA}} \\
104.9^{\mathrm{aA}} \\
99.2\end{array}$ & $\begin{array}{l}107.3^{\mathrm{aA}} \\
101.2^{\mathrm{cdB}} \\
106.9^{\mathrm{aA}} \\
105.1\end{array}$ & $\begin{array}{l}74.6^{\mathrm{eB}} \\
97.2^{\mathrm{dA}} \\
72.4^{\mathrm{cB}} \\
81.8\end{array}$ & $\begin{array}{l}94.5^{\mathrm{cA}} \\
92.5^{\mathrm{eA}} \\
94.5^{\mathrm{bA}} \\
93.8^{4}\end{array}$ & $\begin{array}{l}66.2^{\mathrm{fC}} \\
91.5^{\mathrm{eA}} \\
79.6^{\mathrm{cB}} \\
79.1\end{array}$ & $\begin{array}{r}97.2 \\
101.3 \\
99.5 \\
99.4\end{array}$ & $\begin{array}{l}* * \\
* * \\
* *\end{array}$ & $\begin{array}{l}2.66 \\
2.44 \\
5.17\end{array}$ \\
\hline $\mathrm{T} / \mathrm{P}$ & $\begin{array}{l}\text { WS17 } \\
\text { DS17/18 } \\
\text { WS18 } \\
\text { Mean }\end{array}$ & $\begin{array}{l}23 \\
25 \\
22 \\
23.4\end{array}$ & $\begin{array}{l}22 \\
22 \\
21 \\
21.8\end{array}$ & $\begin{array}{l}20 \\
23 \\
21 \\
21.4\end{array}$ & $\begin{array}{l}24 \\
23 \\
23 \\
23.1\end{array}$ & $\begin{array}{l}22 \\
22 \\
23 \\
22.4\end{array}$ & $\begin{array}{l}23 \\
22 \\
22 \\
22.4\end{array}$ & $\begin{array}{l}23 \\
19 \\
28 \\
23.4\end{array}$ & $\begin{array}{l}24 \\
21 \\
17 \\
20.8\end{array}$ & $\begin{array}{l}24 \\
20 \\
19 \\
20.8\end{array}$ & $\begin{array}{l}23 \\
21 \\
25 \\
23.0\end{array}$ & $\begin{array}{l}23 \\
22 \\
22 \\
22.2\end{array}$ & $\begin{array}{l}\mathrm{ns} \\
\mathrm{ns} \\
\mathrm{ns}\end{array}$ & $\begin{array}{r}10.36 \\
8.76 \\
21.99\end{array}$ \\
\hline $\mathrm{P} / \mathrm{P}$ & $\begin{array}{l}\text { WS17 } \\
\text { DS17/18 } \\
\text { WS18 } \\
\text { Mean }\end{array}$ & $\begin{array}{l}14 \\
14 \\
14 \\
14.0\end{array}$ & $\begin{array}{l}12 \\
12 \\
12 \\
12.0\end{array}$ & $\begin{array}{l}12 \\
11 \\
12 \\
11.7\end{array}$ & $\begin{array}{l}14 \\
13 \\
13 \\
13.3\end{array}$ & $\begin{array}{l}12 \\
12 \\
13 \\
12.3\end{array}$ & $\begin{array}{l}13 \\
13 \\
13 \\
13.0\end{array}$ & $\begin{array}{l}12 \\
12 \\
13 \\
12.3\end{array}$ & $\begin{array}{l}14 \\
14 \\
14 \\
14.0\end{array}$ & $\begin{array}{l}14 \\
14 \\
14 \\
14.0\end{array}$ & $\begin{array}{l}13 \\
13 \\
13 \\
13.0\end{array}$ & $\begin{array}{l}13 \\
13 \\
13 \\
13.0\end{array}$ & $\begin{array}{l}\mathrm{ns} \\
\mathrm{ns} \\
\mathrm{ns}\end{array}$ & $\begin{array}{r}19.18 \\
17.52 \\
7.34\end{array}$ \\
\hline $\begin{array}{l}\text { PL } \\
(\mathrm{cm})\end{array}$ & $\begin{array}{l}\text { WS17 } \\
\text { DS17/18 } \\
\text { WS18 } \\
\text { Mean }\end{array}$ & $\begin{array}{l}22.8^{\mathrm{aA}} \\
20.3^{\mathrm{bB}} \\
20.6^{\mathrm{bcB}} \\
21.2^{2}\end{array}$ & $\begin{array}{l}21.9^{\mathrm{abA}} \\
22.9^{\mathrm{abA}} \\
21.5^{\mathrm{abA}} \\
22.1\end{array}$ & $\begin{array}{l}22.1^{\mathrm{aA}} \\
22.7^{\mathrm{aA}} \\
21.2^{\mathrm{abcA}} \\
22.0\end{array}$ & $\begin{array}{l}21.7^{\text {abA }} \\
20.9^{\text {abA }} \\
21.4^{\text {abcA }} \\
21.3\end{array}$ & $\begin{array}{l}21.1^{\mathrm{bA}} \\
20.6^{\mathrm{abB}} \\
22.2^{\mathrm{abA}} \\
21.3\end{array}$ & $\begin{array}{l}21.6^{\mathrm{bA}} \\
20.9^{\mathrm{abA}} \\
21.5^{\mathrm{abcA}} \\
21.3\end{array}$ & $\begin{array}{l}21.8^{\mathrm{abB}} \\
21.6^{\mathrm{abB}} \\
24.6^{\mathrm{aA}} \\
22.7\end{array}$ & $\begin{array}{l}17.4^{\mathrm{cA}} \\
17.8^{\mathrm{cA}} \\
18.0^{\mathrm{cA}} \\
17.7^{4}\end{array}$ & $\begin{array}{l}16.9^{\mathrm{cB}} \\
19.8^{\mathrm{bA}} \\
19.8^{\mathrm{bcA}} \\
18.8\end{array}$ & $\begin{array}{l}17.2^{\mathrm{cA}} \\
15.0^{\mathrm{cB}} \\
18.8^{\mathrm{bcA}} \\
17.0\end{array}$ & $\begin{array}{l}20.5 \\
20.2 \\
20.9 \\
20.7\end{array}$ & $\begin{array}{l}* * \\
* * \\
*\end{array}$ & $\begin{array}{r}3.26 \\
6.87 \\
10.62\end{array}$ \\
\hline $\begin{array}{l}\text { SS } \\
(\%)\end{array}$ & $\begin{array}{l}\text { WS17 } \\
\text { DS17/18 } \\
\text { WS18 } \\
\text { Mean }\end{array}$ & $\begin{array}{l}98.0^{\mathrm{aA}} \\
94.3^{\mathrm{abcB}} \\
84.6^{\mathrm{abC}} \\
92.3^{2}\end{array}$ & $\begin{array}{l}94.2^{\mathrm{cB}} \\
96.0^{\mathrm{aA}} \\
82.3^{\mathrm{abC}} \\
90.8\end{array}$ & $\begin{array}{l}96.0^{\mathrm{bA}} \\
95.6^{\mathrm{abA}} \\
84.9^{\mathrm{abB}} \\
92.1\end{array}$ & $\begin{array}{l}94.0^{\mathrm{cA}} \\
95.9^{\mathrm{aA}} \\
91.0^{\mathrm{aB}} \\
93.6\end{array}$ & $\begin{array}{l}94.3^{\mathrm{cA}} \\
95.3^{\mathrm{abcA}} \\
89.8^{\mathrm{abB}} \\
93.1\end{array}$ & $\begin{array}{l}95.8^{\mathrm{bA}} \\
96.1^{\mathrm{aA}} \\
85.6^{\mathrm{abB}} \\
92.5\end{array}$ & $\begin{array}{l}93.6^{\mathrm{cdA}} \\
93.2^{\mathrm{cA}} \\
87.8^{\mathrm{abB}} \\
91.5\end{array}$ & $\begin{array}{l}96.9^{\mathrm{abA}} \\
93.9^{\mathrm{abcB}} \\
85.0^{\mathrm{abC}} \\
91.9\end{array}$ & $\begin{array}{l}88.7^{\mathrm{eB}} \\
93.4^{\mathrm{bcA}} \\
86.7^{\mathrm{abB}} \\
89.6\end{array}$ & $\begin{array}{l}92.3^{\mathrm{dA}} \\
67.2^{\mathrm{dC}} \\
78.9^{\mathrm{bB}} \\
79.5^{4}\end{array}$ & $\begin{array}{l}94.4 \\
92.1 \\
85.7 \\
90.7\end{array}$ & $\begin{array}{l}* * \\
* * \\
* *\end{array}$ & $\begin{array}{l}0.89 \\
1.46 \\
8.04\end{array}$ \\
\hline $\begin{array}{l}\text { GW } \\
(\mathrm{g})\end{array}$ & $\begin{array}{l}\text { WS17 } \\
\text { DS17/18 } \\
\text { WS18 } \\
\text { Mean }\end{array}$ & $\begin{array}{l}3.20^{\mathrm{aA}} \\
3.18^{\mathrm{aA}} \\
2.95^{\mathrm{aB}} \\
3.11\end{array}$ & $\begin{array}{l}2.97^{\mathrm{abcA}} \\
3.04^{\mathrm{abA}} \\
2.88^{\mathrm{aB}} \\
2.96\end{array}$ & $\begin{array}{l}3.23^{\mathrm{aA}} \\
3.20^{\mathrm{aA}} \\
2.89^{\mathrm{aB}} \\
3.11\end{array}$ & $\begin{array}{l}2.80^{\mathrm{abcA}} \\
2.72^{\mathrm{bcB}} \\
2.96^{\mathrm{aA}} \\
2.83\end{array}$ & $\begin{array}{l}3.10^{\mathrm{aA}} \\
2.96^{\mathrm{abA}} \\
2.89^{\mathrm{aB}} \\
2.98\end{array}$ & $\begin{array}{l}3.03^{\mathrm{abA}} \\
3.01^{\mathrm{abA}} \\
3.00^{\mathrm{aA}} \\
3.01\end{array}$ & $\begin{array}{l}3.23^{\mathrm{aA}} \\
3.25^{\mathrm{aA}} \\
2.96^{\mathrm{aB}} \\
3.15\end{array}$ & $\begin{array}{l}2.53^{\mathrm{cA}} \\
2.57^{\mathrm{cA}} \\
2.57^{\mathrm{bA}} \\
2.56\end{array}$ & $\begin{array}{l}2.63^{\mathrm{bcA}} \\
2.58^{\mathrm{cB}} \\
2.53^{\mathrm{bB}} \\
2.58\end{array}$ & $\begin{array}{l}2.90^{\mathrm{abcB}} \\
3.21^{\mathrm{aA}} \\
2.51^{\mathrm{bC}} \\
2.87\end{array}$ & $\begin{array}{l}2.96 \\
2.97 \\
2.81 \\
2.92\end{array}$ & $\begin{array}{l}* \\
* * \\
* *\end{array}$ & $\begin{array}{l}8.99 \\
6.96 \\
2.81\end{array}$ \\
\hline $\begin{array}{l}\text { Gy/Po } \\
\text { (kg) }\end{array}$ & $\begin{array}{l}\text { WS17 } \\
\text { DS17/18 } \\
\text { WS18 } \\
\text { Mean }\end{array}$ & $\begin{array}{l}7.28^{\mathrm{aA}} \\
7.54^{\mathrm{aA}} \\
5.00^{\mathrm{aB}} \\
6.61\end{array}$ & $\begin{array}{l}5.30^{\mathrm{bB}} \\
6.06^{\mathrm{bcA}} \\
5.30^{\mathrm{aB}} \\
5.55\end{array}$ & $\begin{array}{l}5.20^{\mathrm{bA}} \\
5.34^{\mathrm{cdA}} \\
5.27^{\mathrm{aA}} \\
5.27\end{array}$ & $\begin{array}{l}4.31^{\mathrm{cB}} \\
5.67^{\mathrm{cdA}} \\
4.66^{\mathrm{aB}} \\
4.88\end{array}$ & $\begin{array}{l}5.15^{\mathrm{bB}} \\
7.20^{\mathrm{abA}} \\
5.35^{\mathrm{aB}} \\
5.90\end{array}$ & $\begin{array}{l}5.19^{\mathrm{bA}} \\
5.45^{\mathrm{cdA}} \\
4.73^{\mathrm{aB}} \\
5.12\end{array}$ & $\begin{array}{l}5.15^{\mathrm{bB}} \\
5.40^{\mathrm{cdA}} \\
5.40^{\mathrm{aA}} \\
5.32\end{array}$ & $\begin{array}{l}3.81^{\mathrm{cA}} \\
3.73^{\mathrm{eA}} \\
3.09^{\mathrm{bB}} \\
3.54\end{array}$ & $\begin{array}{l}3.69^{\mathrm{cB}} \\
4.47^{\mathrm{deA}} \\
3.04^{\mathrm{bC}} \\
3.73\end{array}$ & $\begin{array}{l}4.00^{\mathrm{cB}} \\
5.27^{\mathrm{cdA}} \\
3.13^{\mathrm{bC}} \\
4.13\end{array}$ & $\begin{array}{l}4.91 \\
5.61 \\
4.50 \\
5.01\end{array}$ & $\begin{array}{l}* * \\
* * \\
* *\end{array}$ & $\begin{array}{r}9.46 \\
13.80 \\
10.01\end{array}$ \\
\hline
\end{tabular}

Different small letters in each row (agronomic traits) are significantly different at $p<0.05$. Different capital letters in the column (genotype) between seasons are significantly different at $p<0.05$.

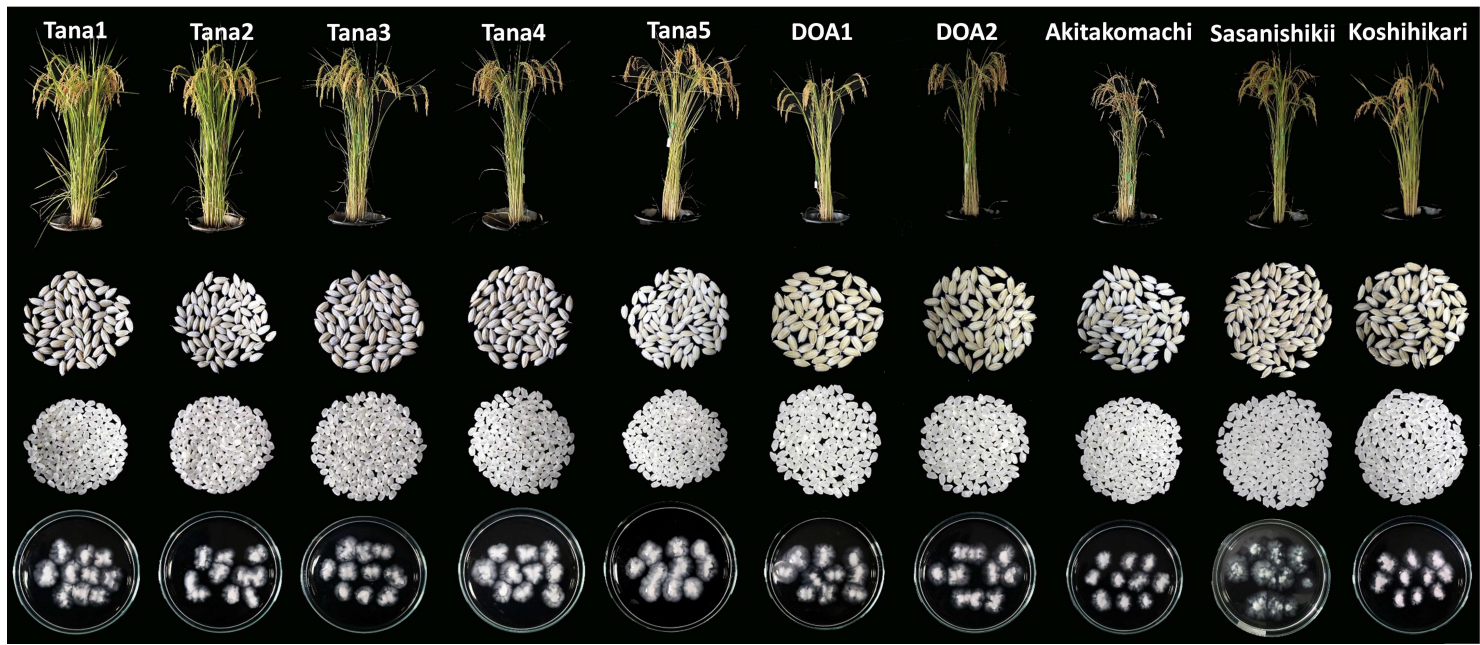

Fig. 1 Plant type, paddy grains, milled grains and alkaline test results of five candidate lines as well as DOA1, DOA2, $\mathrm{AK}, \mathrm{SN}$ and $\mathrm{KH}$ in DS17/18. 
than those of AK, SN and KH (66-94 cm in WS17, 91-97 $\mathrm{cm}$ in DS17/18 and 72-94 cm in WS18). These results may be affected by the relatively low $\mathrm{DF}$ values for $\mathrm{AK}, \mathrm{SN}$ and $\mathrm{KH}$. In addition, when Tana1 was compared with DOA2, there were no significant differences in DF or PH.

The average PL among lines/varieties in each season were significantly different $(p<0.05)$ whereas the average PL among seasons in each line/variety were significantly different $(p<0.05)$ in Tana1, Tana5, DOA2, SS and $\mathrm{KH}$, except for Tana2, Tana3, Tana4, DOA1 and AK. However, the PL of the five candidate lines in all three seasons was slightly different from that of DOA2 while the $\mathrm{PL}$ of AK, SN and $\mathrm{KH}$ in all three seasons was shorter than that of the other lines/varieties (Table 3). The SS of all lines/cultivars in WS17 and DS17/18 were higher than that in WS18 except for SN and $\mathrm{KH}$. Moreover, KH presented the lowest SS in DS17/18 (67.18\%). Lastly, the Gy/Po of Tana1 in WS17 $(7.28 \mathrm{~kg})$ and DS17/18 $(7.54 \mathrm{~kg})$ was higher compared with that of the other lines/varieties and was higher than that of the original variety, DOA2 (5.15 kg in WS17 and $5.40 \mathrm{~kg}$ in DS17/18) and higher than that of AK $(3.81 \mathrm{~kg}$ in WS17 and $3.73 \mathrm{~kg}$ in DS17/18). On the other hand, the Gy/Po of Tana1 in WS18 was lower than that in WS17 and DS17/18. However, the Gy/Po of Tana1-Tana5 in WS18 were not significantly different from the value of DOA2 (Table 3). In addition, the Gy/Po of almost every line/variety in DS17/18 was higher than that in WS17 and WS18. Thus, Tana1 selected via the pure-line method should produce higher grain yields than DOA2.

\section{The stability of grain yield}

The results of the GGE biplot analysis of grain yield stability are shown in Fig. 2. The relationship between the mean Gy/Po and PCA1 indicated that the lines/cultivars whose mean Gy/Po in the three seasons was higher than the mean Gy/Po $(5.01 \mathrm{~kg})$ were Tana1 $(6.61 \mathrm{~kg})$, Tana5 $(5.90 \mathrm{~kg})$, Tana2 $(5.55 \mathrm{~kg}), \mathrm{DOA} 2(5.32 \mathrm{~kg})$ and Tana $3(5.27 \mathrm{~kg})$ (Table 3). However, the difference in seasons affected the Gy/Po of every line/variety. DS17/18 had the highest mean Gy/Po $(5.61 \mathrm{~kg})$, followed by WS17 $(4.91 \mathrm{~kg})$ and WS $(4.50 \mathrm{~kg})$. In addition, SN had the lowest PCA1 (0.16) (Fig. 2a). These findings mean that SN had a highly stable Gy/Po, but this cultivar had low yield. When stability among the five candidate lines was considered, it was found that Tana5 was highly stable. The biplot graph between PCA1 and PCA2 of Gy/Po in Fig. 2b explains why the five candidate lines were specific to the season. Tana1 showed good adaptation in WS17 while Tana5 and Tana2 showed good adaptation in DS17/18 and WS18, respectively.

\section{Sensory qualities of cooked rice}

Sensory tests were used to provide a score for the overall eating quality according to the Tana Grain Co. Ltd. protocol. As shown in Table 4, DOA2 had the highest scores of characteristics (4.0), flavor (4.0), aroma (4.0) and average score (3.9). However, the scores of every characteristic of Tana1 were not significantly different from those of DOA2, and Tana1 had a mean score of 3.85. On the other hand, product sample 2 (a control) had the lowest average score (2.15). When the japonica varieties derived from Japan were considered, including AK, SN and $\mathrm{KH}$, it was found that the average scores were lower (2.25-2.75) than those of DOA1, DOA2 and Tana1. For Tana5, which had a high yield, as did Tana1, the average score was only 2.7 , which was significantly lower than that of both DOA2 and Tana1.

\section{Grain quality}

The $F$-values of grain quality were also different among the lines/varieties except for AT, whose grain quality was not significantly different from that of the other lines/varieties (Table 4, Fig. 1). The paddy grain width/length of Tana1 $(3.73 / 7.92 \mathrm{~mm})$ and Tana $3(3.76 / 7.98 \mathrm{~mm})$ was the highest compared with that of the other lines/varieties while the paddy grain width/length of $\mathrm{AK}, \mathrm{SN}$ and $\mathrm{KH}$ was $3.26 / 7.32 \mathrm{~mm}, 3.06 / 7.13 \mathrm{~mm}$ and $3.36 / 6.91 \mathrm{~mm}$, respectively (Table 4 ). In addition, the milled grain width of Tana1 $(3.22 \mathrm{~mm})$ was not significantly different from that of DOA1 and DOA2 (3.14 and $3.16 \mathrm{~mm}$, respectively) while the milled grain length of Tana1 $(5.36 \mathrm{~mm})$ was significantly different from that of DOA1 and DOA2 (3.14 and $3.16 \mathrm{~mm}$, respectively) (Table 4). However, both the paddy and milled grain size of Tana1 and the other candidate lines were in accordance with the standard size of those of japonica rice [28].

The GE of the five candidate lines (2.01$2.19 \mathrm{~mm}$ ) was more elongated than that of AK, $\mathrm{SN}$ and $\mathrm{KH}(1.78-1.97 \mathrm{~mm})$, but there were no significant differences with that of DOA1 or DOA2 (2.06 and $2.04 \mathrm{~mm}$, respectively) (Table 4). The AT results among the lines/varieties were not significant, as shown in Table 4 and Fig. 1. Lastly, the amylose content was the lowest $(17.83 \%)$ in $\mathrm{KH}$, and the GE of the other lines/varieties varied from 21.12-22.96 mm (Table 4). 

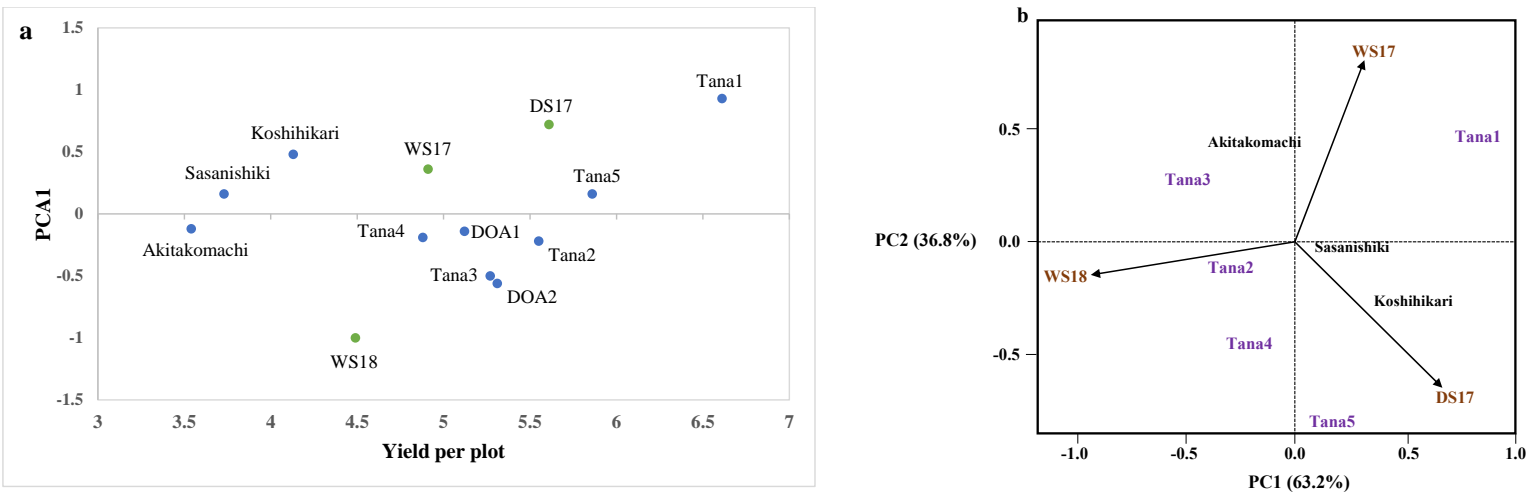

Fig. 2 (a) Biplot graph of the PC1 score versus the mean grain yield per plant of 10 lines/varieties in different seasons and (b) biplot graph of the PC1 score versus the PC2 score for the grain yield of 10 lines/varieties.

Table 4 The means of the sensory tests and cooking quality of 5 candidate lines compared with control varieties from Phan, Chiang Rai province, in DS17/18.

\begin{tabular}{|c|c|c|c|c|c|c|c|c|c|c|c|c|c|}
\hline \multirow{2}{*}{ Variety } & \multicolumn{6}{|c|}{ Sensory item } & \multicolumn{2}{|c|}{ Paddy GS (mm) } & \multicolumn{2}{|c|}{ Milled GS (mm) } & \multirow{2}{*}{$\begin{array}{c}\mathrm{GE} \\
(\mathrm{mm})\end{array}$} & \multirow[t]{2}{*}{ AT } & \multirow{2}{*}{$\begin{array}{l}\mathrm{AC} \\
(\%)\end{array}$} \\
\hline & Appearance & Flavor & Aroma & Softness & Adhesiveness & Mean & Width & Length & Width & Length & & & \\
\hline Tana1 & $4.00^{\mathrm{a}}$ & $3.75^{\mathrm{ab}}$ & $3.75^{\mathrm{ab}}$ & $4.00^{\mathrm{a}}$ & $3.75^{\mathrm{a}}$ & $3.85^{\mathrm{a}}$ & $3.73^{\mathrm{a}}$ & $7.92^{\mathrm{a}}$ & $3.22^{\mathrm{a}}$ & $5.36^{\mathrm{b}}$ & $2.01^{\mathrm{abc}}$ & 6 & $21.62^{\mathrm{bcc}}$ \\
\hline Tana2 & $3.00^{\mathrm{b}}$ & $2.75^{\mathrm{bc}}$ & $3.00^{\mathrm{abc}}$ & $3.00^{\mathrm{abcd}}$ & $3.00^{\mathrm{ab}}$ & $2.95^{\mathrm{b}}$ & $3.57^{\mathrm{b}}$ & $7.67^{\mathrm{b}}$ & $3.17^{\mathrm{ab}}$ & $5.44^{\mathrm{a}}$ & $2.13^{\mathrm{ab}}$ & 6 & $22.96^{\mathrm{a}}$ \\
\hline Tana3 & $2.25^{\mathrm{bc}}$ & $2.25^{\mathrm{c}}$ & $2.50^{c}$ & $2.25^{\mathrm{cd}}$ & $2.75^{\mathrm{abc}}$ & $2.40^{\text {cde }}$ & $3.76^{\mathrm{a}}$ & $7.98^{\mathrm{a}}$ & $3.13^{\mathrm{bc}}$ & $5.23^{\mathrm{d}}$ & $2.06^{\mathrm{abc}}$ & 6 & $21.54^{\mathrm{bcc}}$ \\
\hline Tana4 & $2.50^{\mathrm{bc}}$ & $2.50^{\mathrm{c}}$ & $2.75^{\mathrm{bc}}$ & $1.75^{\mathrm{d}}$ & $2.50^{\text {bcd }}$ & $2.40^{\text {cde }}$ & $3.22^{\mathrm{d}}$ & $7.37^{\text {de }}$ & $3.10^{\mathrm{bc}}$ & $5.27^{c}$ & $2.19^{\mathrm{a}}$ & 6 & $21.34^{\text {bcc }}$ \\
\hline Tana5 & $2.50^{\mathrm{bc}}$ & $2.75^{\mathrm{bc}}$ & $2.75^{\mathrm{bc}}$ & $2.25^{\mathrm{cd}}$ & $3.25^{\mathrm{ab}}$ & $2.70^{\mathrm{bc}}$ & $3.61^{b}$ & $7.67^{\mathrm{b}}$ & $3.07^{\mathrm{c}}$ & $5.19^{\mathrm{e}}$ & $2.04^{\mathrm{abc}}$ & 6 & $22.03^{\mathrm{bc}}$ \\
\hline DOA1 & $3.00^{\mathrm{b}}$ & $2.75^{\mathrm{bc}}$ & $2.75^{\mathrm{bc}}$ & $3.35^{\mathrm{abc}}$ & $3.00^{\mathrm{ab}}$ & $3.00^{\mathrm{b}}$ & $3.53^{\mathrm{b}}$ & $7.55^{\mathrm{bc}}$ & $3.14^{\mathrm{abc}}$ & $5.42^{\mathrm{a}}$ & $2.06^{\mathrm{abc}}$ & 6 & $22.17^{\mathrm{ab}}$ \\
\hline DOA2 & $4.00^{\mathrm{a}}$ & $4.00^{\mathrm{a}}$ & $4.00^{\mathrm{a}}$ & $3.75^{\mathrm{ab}}$ & $3.75^{a}$ & $3.90^{\mathrm{a}}$ & $3.57^{\mathrm{b}}$ & $7.52^{\mathrm{bcd}}$ & $3.16^{\mathrm{abc}}$ & $5.46^{\mathrm{a}}$ & $2.04^{\mathrm{abc}}$ & 6 & $21.91^{b c c}$ \\
\hline AK & $2.00^{c}$ & $2.50^{c}$ & $2.75^{\mathrm{bc}}$ & $1.75^{\mathrm{d}}$ & $2.25^{\mathrm{bcd}}$ & $2.25^{\mathrm{de}}$ & $3.26^{\mathrm{cd}}$ & $7.32^{\text {de }}$ & $2.80^{\mathrm{e}}$ & $5.18^{\mathrm{e}}$ & $1.92^{\mathrm{cd}}$ & 5 & $21.12^{\mathrm{d}}$ \\
\hline SN & $2.50^{\mathrm{bc}}$ & $2.50^{c}$ & $2.75^{\mathrm{bc}}$ & $2.50^{\text {bcd }}$ & $2.75^{a b c}$ & $2.60^{\mathrm{bcc}}$ & $3.06^{\mathrm{e}}$ & $7.13^{\mathrm{e}}$ & $2.86^{\text {de }}$ & $5.06^{\mathrm{g}}$ & $1.97^{\mathrm{bcd}}$ & 5 & $22.31^{\mathrm{ab}}$ \\
\hline $\mathrm{KH}$ & $3.00^{\mathrm{b}}$ & $2.75^{\mathrm{bc}}$ & $2.75^{b c}$ & $2.50^{\mathrm{bcd}}$ & $2.75^{\mathrm{abc}}$ & $2.75^{\mathrm{bc}}$ & $3.36^{\mathrm{c}}$ & $6.91^{f}$ & $2.95^{\mathrm{d}}$ & $5.15^{\text {ef }}$ & $1.78^{\mathrm{d}}$ & 5 & $17.83^{\mathrm{e}}$ \\
\hline PS 1 & $2.25^{\mathrm{bc}}$ & $3.00^{\mathrm{abc}}$ & $3.25^{\mathrm{abc}}$ & $2.25^{\mathrm{cd}}$ & $1.75^{\mathrm{cd}}$ & $2.50^{\text {cde }}$ & e & - & - & - & - & - & - \\
\hline PS 2 & $2.00^{c}$ & $2.75^{\mathrm{bc}}$ & $2.75^{b c}$ & $1.75^{\mathrm{d}}$ & $1.50^{\mathrm{d}}$ & $2.15^{\mathrm{e}}$ & - & - & - & - & - & - & - \\
\hline Mean & 2.70 & 2.85 & 2.98 & 2.59 & 2.75 & 2.79 & 3.46 & 7.50 & 3.06 & 5.27 & 2.02 & 5.7 & 21.47 \\
\hline$F$-test & $* *$ & $*$ & $*$ & $* *$ & $* *$ & $* *$ & $* *$ & $* *$ & $* *$ & 0.5 & 2.08 & ns & $* *$ \\
\hline$\% \mathrm{CV}$ & 21.62 & 30.3 & 27.21 & 33.43 & 28.43 & 11.62 & 1.76 & 1.54 & 1.78 & 0.45 & 7.88 & 0.02 & 2.17 \\
\hline
\end{tabular}

Different letters in the column (sensory tests and cooking quality) are significantly different at $p<0.05$.

PS is Product sample.

\section{Phylogenetic relationships among five candidate lines and control varieties}

According to the GBS results of the five candidate lines and control varieties, a phylogenetic tree showing the relationships among the ten lines/cultivars was constructed (Fig. 3). The phylogenetic tree was divided into two groups. Group I contained five candidate lines together with DOA1 and DOA2, which had slightly different bases in their genome. In addition, the genetic background of Tana5 in group I was closely related to that of DOA2, which showed the base difference of only $27 \mathrm{bp}$ in the whole genome; however, Tana3 was closely related to DOA1 (21 SNP positions). In addition, Tana1, which performed well in the yield trials, was separate from group I but was not much different from the others in this group. On the other hand, group II contained three varieties that were introduced from Japan, including $\mathrm{KH}, \mathrm{SN}$ and $\mathrm{AK}$, which showed SNP differences ranging from 4035-5490 positions throughout the whole genome. Thus, DOA2 and AK currently exhibit a difference in their genetic background (7560 SNP positions). Moreover, DOA1 and $\mathrm{SN}$ also exhibit a difference in their genetic background (5283 SNP positions), and DOA1 and DOA2, which farmers used to grow in the northern part of Thailand, were found to be closely related (28 SNP positions).

\section{DISCUSSION}

\section{Genotype and environmental effects on agronomic traits and yield}

The six japonica rice varieties exhibited variation in each agronomic trait and yield when they were 


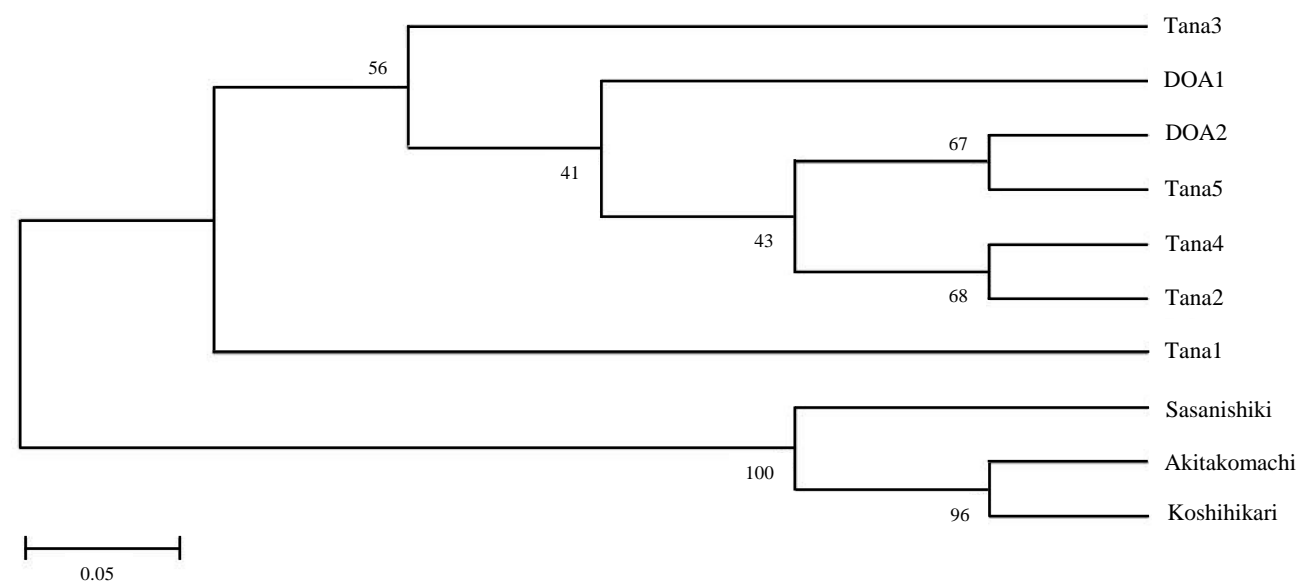

Fig. 3 A phylogenetic tree of 5 candidate lines and controlled varieties based on genotype by sequencing. The phylogenetic tree was classified into 2 groups. Group I comprises Tana1-5, DOA1 and DOA2 while group II comprises the japonica varieties introduced from Japan, including $\mathrm{AK}, \mathrm{SN}$ and $\mathrm{KH}$. The numbers at the node indicate the percentage obtained with 1000 bootstraps.

grown in different locations. In general, japonica rice originated in a temperate climate. Thus, japonica rice should be sensitive to high temperatures such as those that occur in Thailand. However, the DOA1 and DOA2 varieties are suitable for growth in areas where the average temperature is approximately $18-25^{\circ} \mathrm{C}$ and their resistance to hot weather is stronger than that of other Japanese rice varieties [3]. These two varieties can grow in both wet and dry seasons. In Experiment 1, it could be confirmed that DOA1 and DOA2 still produced high yields compared with those of other japonica varieties in the Phan district. However, the daytime/nighttime temperatures in both KPS and Phan in Experiment 1 were higher than the recommended values, especially in KPS. Thus, the grain yield of each variety in KPS was lower than that in Phan. These results can be explained by heat units during the crop growth period. The occurrence of various phenological events can be estimated by computing accumulated heat units, which provide an estimate of harvest date [29]. Therefore, with respect to japonica rice that is grown under high temperatures, the accumulation of heat units occurs faster than that under low temperatures, which reduces growth and development in the vegetative phase and reduces the accumulation of biomass. These results can decrease the life cycle of rice plants [3]. In this experiment, the average temperature in KPS was higher than that in Phan by approximately $2^{\circ} \mathrm{C}$. Thus, the accumulation of heat units in KPS in the vegetative stage finished earlier than that in Phan.
Therefore, the agronomic traits and yield of all the varieties in KPS were lower than those in Phan. Thus, the northern part of Thailand rather than the central part is suitable for growing japonica rice [3]. In this experiment, compared with other varieties, DOA2 produced the highest yield in both KPS and Phan. However, the yield of DOA2 in KPS was lower than that in Phan. In previous research on japonica rice in Thailand, AK was evaluated in farmers' fields in northern and northeastern Thailand between 1992 and 1995; it was then recommended to plant a different variety, namely DOA2, in 1995 [3]. Thus, at present, DOA2 is still a good japonica variety to grow in the northern part of Thailand. However, the DOA2 was not uniform and produced off-type plants in farmers' fields in Chiang Rai [18]. Thus, this research involved the recollection of DOA2 germplasm from three sources and started the selection of good plants via pure-line selection.

\section{Genetic background of DOA1 and DOA2}

In the history of japonica rice research in Thailand, $\mathrm{SN}$ and AK showed good performance in terms of agronomic traits and yield in yield trials with other japonica varieties in northern areas in Thailand. Afterward, the Rice Department of the Ministry of Agriculture and Cooperative released the DOA1 and DOA2 varieties as recommended ones [2,3]. However, these varieties produced many off-type plants in farmers' fields in Chiang Rai province [18]. In addition, the genetic backgrounds of DOA1 and DOA2 were different from those of SN and AK according to an analysis with the double-digest restriction- 
associated DNA (ddRAD) sequencing technique. This result confirmed that the genetic background of DOA1 and DOA2 had already changed. Thus, these results were confirmed again by using the GBS technique and were the same as those of previous reported [18]. DOA1 and DOA2 have been released to farmers since 1995 until now (24 years). The paddy fields that grew DOA1 and DOA2 were also used to grow other indica varieties such as Khao Dawk Hom Mali 105 (long grain type) or RD6 and Sun Pa Tong1 (glutinous rice) [30]. This phenomenon may affect outcrossing in the field for many years. Moreover, contamination can occur at several stages of rice production, including unintentional mixing of seed with that of other varieties during seed preparation, during harvest and during grain processing [31].

\section{Pure-line selection slightly changed the genotype but can improve yields while maintaining good cooking quality}

In the pure-line selection, five candidate lines were selected for yield trials in WS17, DS17/18 and WS18 and were compared with control varieties. In addition, the GBS technique was used to identify differences in genotype. The results showed that the five candidate lines did not seem to generate many different genetic backgrounds compared with that of DOA2, although there were candidate lines that were very different from AK. In addition, among the five candidate lines, there were also slightly different genetic backgrounds. In terms of agronomic traits and grain yield, Tana1 had the greatest yield in WS17 and DS17/18, but its yield was not significantly different from that of DOA2 in WS18. Moreover, the other agronomic traits in the three seasons varied among and within the lines/varieties because the variation within a pure-line population is not heritable due to environmental factors [32]. Thus, in this experiment, the methodology factors including air temperature, relative humidity and amount of rainfall between the wet and dry seasons were different, which then affected grain yield and agronomic traits. However, the genetics of the five candidate lines were slightly altered. This means that selection within the pure-line population can alter the genetic background, albeit not by much. Moreover, Tana1 had good grain quality and cooking quality, both of which were similar to those of DOA2. Thus, the pure-line selection method can slightly alter genotypes, but it can be used to maintain the purity of an existing variety that has become contaminated.

\section{CONCLUSION}

In this research, japonica varieties were found to be suitable to grow in the Phan district rather than in KPS due to weather factors, especially air temperature. Compared with other japonica varieties, DOA2 still showed good performance. However, at the present time, the genotype and phenotype of DOA2 have changed from those of the original variety (AK). Thus, pure-line selection can improve agronomic traits and increase the yield of DOA2. Lastly, Tana1 showed great performance in terms of grain yield, although the grain quality and cooking quality had not changed compared with those of DOA2. In addition, the genetics of Tana1 changed slightly from those of DOA2. Thus, DOA2 can be replaced with Tana1 and can be grown in northern Thailand, especially in Chiang Rai province.

Acknowledgements: The authors would like to acknowledge the Tana Group International Co. Ltd., Thailand for financing the study and the provision of this research.

\section{Appendix A. Supplementary data}

Supplementary data associated with this article can be found at http://dx.doi.org/10.2306/ scienceasia1513-1874.2020.029

\section{REFERENCES}

1. Kousei A (2010) Present Situation and Future of Japanese Restaurants in Thailand, Bangkok.

2. CRC (2014) Research and Development of Japanese Rice in Thailand, CRC, Rice Department, Thailand. [in Thai]

3. Warinrak B (2013) Japonica Rice Production Technology in Thailand, CRC, Rice Department, Thailand. [in Thai]

4. Tanaka I, Kobayashi A, Tomita K, Takeuchi Y, Yamagishi M, Yano M, Sasaki T, Horiuchi H (2006) Detection of quantitative trait loci for stickiness and appearance based on eating quality test in japonica rice cultivar. Breed Res 8, 39-47. [in Japanese]

5. Takeuchi Y, Hori K, Suzuki K, Nonoue Y, TakemotoKuno Y, Maeda H, Sato H, Hirabayashi $\mathrm{H}$, et al (2008) Major QTLs for eating quality of an elite Japanese rice cultivar, Koshihikari, on the short arm of chromosome 3. Breed Sci 58, 437-445.

6. Wada T, Ogata T, Tsubone M, Uchimura Y, Matsue Y (2008) Mapping of QTLs for eating quality and physicochemical properties of the japonica rice 'Koshihikari'. Breed Sci 58, 427-435.

7. Kobayashi A, Hori K, Yamamoto T, Yano M (2018) Koshihikari: a premium short-grain rice cultivar - its expansion and breeding in Japan. Rice 11, ID 15. 
8. Sugiura K, Honjo H, Hayashi M, Nonoyama T, Yamashita K, Torazawa A, Yamauchi A (2013) Research on the factors affecting kernel quality of rice cultivar 'Koshihikari' cultivated in Aichi prefecture. Crop Sci Soc Jpn 82, 262-269. [in Japanese]

9. Warinrak B (2012) The History of Japanese Rice in Thailand: During the Period from Past to Year 2012, CRC, Rice Department, Thailand. [in Thai]

10. Seemaon K, Yamao M, Hosono K (2015) Production of Japanese rice through contract farming system in Wiang Pa Pao district, Chiang Rai province, Thailand. Am J Rural Dev 3, 41-51.

11. Kawatsu S, Homma K, Horie T, Shiraiwa T (2007) Change of weather condition and its effect on rice production during the past 40 years in Japan. Crop Sci Soc Jpn 76, 423-432. [in Japanese]

12. Suenaga K, Takashima M, Suzuki K (1963) On the new rice variety "SASANISHIKI". Bull Miyagi Agric Exp Stn 33, 104-119.

13. Inoue K (2012) A technical attempt to avoid the high temperature damage during ripening on rice cultivar Koshihikari in Fukui prefecture - focusing on the transplanting time and grain qualities. Hokuriku Crop Sci 47, 137-140. [in Japanese]

14. Iwata $T$ (1992) A report on a japonica rice variety 'Koshihikari' cultivated in foreign countries. Hokuriku Crop Sci 27, 90-93. [in Japanese]

15. Kawamura S, Natsuga M, Kouno S, Itoh K (1996) Taste evaluation of California grown rice of Akitakomachi, Koshihikari and Sasanishiki. J Jpn Soc Food Sci 43, 328-332. [in Japanese]

16. Asian Development Bank (2009) The Economics of Climate Change in Southeast Asia: a Regional Review, Asian Development Bank, Manila, Philippines.

17. Meteorological Development Bureau (2016) Annual weather summary over Thailand 2015. Available at: www.tmd.go.th/programs/uploads/ yearlySummary/annual2015_e.pdf.

18. Nakwilai P, Narumon P, Cheabu S, Saensuk C, Arikit S, Malumpong C (2017) The genotypic and phenotypic comparison in cultivar DOA2 with others japonica and indica rice. Khon Kaen $J$ 45S1, 1045-1056. [in Thai]

19. Rathore RK, Ram M (2013) Role of selection in improving cultivars. Popular Kheti 1, 45-48.

20. Little RR, Hilder GB, Dawson EH (1958) Differential effect of dilute alkali on 25 varieties of milled milled rice. Cereal Chem 35, 111-126.

21. IRRI (2013) Alkali digestion. In: Standard Evaluation System (SES) for Rice, 5th Edn, IRRI, Manila, Philippines, pp 46.

22. Julino BO (1985) Criteria and test for rice grain quality. In: Rice chemistry and technology, AACC, Saint Paul, USA, pp443-513.

23. Juliano BO (1971) A simplified assay for milled rice amylose. Cereal Sci Today 16, 334-340.

24. Langmead B, Salzberg S (2012) Fast gapped-read alignment with Bowtie 2. Nat Methods 9, 357-359.

25. McKenna A, Hanna M, Banks E, Sivachenko A, Cibulskis K, Kernytsky A, Garimella K, Altshuler D, et al (2010) The genome analysis toolkit: a MapReduce framework for analyzing next-generation DNA sequencing data. Genome Res 20, 1297-1303.

26. R Core Team (2014) R: A Language and Environment for Statistical Computing, R Foundation for Statistical Computing, Vienna, Austria.

27. Gauch HG (1988) Model selection and validation for yield trials with interaction. Biometrics 44, 705-715.

28. Julino BO, Villareak CP (1993) Grain Quality Evaluation of World Rice, IRRI, Manila, Philippines.

29. Yoshida S (1981) Fundamental of Rice Crop Science, IRRI, Manila, Philippines.

30. CRC (2018) Rice Production and Marketing in Chiang Rai, CRC, Thailand. [in Thai]

31. Chamarerk V, Cobelli P, Jairin J, Mekwattanakarn P, Leelakud P, Wongnongwa J (2016) Development of molecular markers for purity testing in Thai jasmine rice. Adv Eco Env Res 1, 35-44.

32. Acquaah G (2012) Principles of Plant Genetics and Breeding, 2nd edn, Wiley-Blackwell, USA. 


\section{Appendix A. Supplementary data}

Table S1 The soil nutrients compared between KPS and Phan districts.

\begin{tabular}{lrr}
\hline Soil nutrient & KPS & Phan \\
\hline Soil pH & 5.80 & 5.40 \\
Organic matter (\%) & 3.82 & 1.56 \\
Total N (mg/kg) & 1000 & 700 \\
Available P (mg/kg) & 29.45 & 26.70 \\
Exchangeable K (mg/kg) & 59.30 & 75.54 \\
Exchangeable Ca (mg/kg) & 1120.20 & 629.00 \\
Exchangeable Mg (mg/kg) & 69.73 & 76.50 \\
\hline
\end{tabular}

Table S2 The weather data in the WS16 from Jun-Oct between KPS and Phan district.

\begin{tabular}{lcccccccccc}
\hline \multirow{2}{*}{ Month } & \multicolumn{2}{c}{ Day Temp $\left({ }^{\circ} \mathrm{C}\right)$} & \multicolumn{2}{c}{ Night Temp $\left({ }^{\circ} \mathrm{C}\right)$} & \multicolumn{2}{c}{ Day RH (\%) } & \multicolumn{2}{c}{ Night RH (\%) } & \multicolumn{2}{c}{ Rainfall (mm) } \\
\cline { 2 - 12 } & KPS & Phan & KPS & Phan & KPS & Phan & KPS & Phan & KPS & Phan \\
\hline Jun & 31.1 & 31.2 & 28.3 & 24.6 & 54.4 & 40.1 & 94.2 & 83.5 & 119.4 & 348.5 \\
Jul & 32.1 & 30.5 & 29.2 & 25.4 & 60.8 & 58.4 & 98.3 & 78.4 & 112.9 & 332.9 \\
Aug & 34.3 & 31.2 & 26.8 & 26.7 & 54.5 & 63.4 & 97.2 & 99.5 & 120.5 & 396.7 \\
Sep & 33.4 & 31.4 & 26.4 & 25.3 & 52.5 & 73.2 & 73.5 & 97.3 & 127.6 & 277.3 \\
Oct & 34.5 & 30.6 & 27.4 & 25.5 & 67.3 & 45.8 & 85.2 & 92.2 & 227.8 & 164.9 \\
\hline Mean & 33.1 & 31.0 & 27.6 & 25.5 & 57.9 & 56.2 & 89.7 & 93.1 & 141.6 & 304.1 \\
\hline
\end{tabular}

Table S3 The weather data in WS17, DS17/18 and WS18 in the yield trials in Phan, Chiang Rai province.

\begin{tabular}{|c|c|c|c|c|c|}
\hline \multirow{2}{*}{ Month } & \multicolumn{2}{|c|}{ Temperature $\left({ }^{\circ} \mathrm{C}\right)$} & \multicolumn{2}{|c|}{ RH (\%) } & \multirow{2}{*}{$\begin{array}{c}\text { Rainfall } \\
\text { (mm) }\end{array}$} \\
\hline & Day & Night & Day & Night & \\
\hline \multicolumn{6}{|l|}{ WS17 } \\
\hline May 2017 & 29.38 & 25.19 & 74.32 & 87.99 & 297.2 \\
\hline Jun 2017 & 29.26 & 25.49 & 77.19 & 90.41 & 207.3 \\
\hline Jul 2017 & 27.99 & 24.66 & 82.64 & 93.13 & 390.0 \\
\hline Aug 2017 & 28.50 & 25.15 & 81.51 & 92.38 & 349.9 \\
\hline Sep 2017 & 28.35 & 24.86 & 81.50 & 92.63 & 280.2 \\
\hline Mean & 28.70 & 25.07 & 79.43 & 91.31 & 304.9 \\
\hline \multicolumn{6}{|l|}{ DS17/18 } \\
\hline Dec 2017 & 23.27 & 17.94 & 74.39 & 91.29 & 79.0 \\
\hline Jan 2018 & 23.58 & 18.77 & 76.97 & 91.62 & 5.4 \\
\hline Feb 2018 & 25.96 & 19.69 & 70.56 & 89.26 & 20.5 \\
\hline Mar 2018 & 27.82 & 22.20 & 70.51 & 89.13 & 14.3 \\
\hline Apr 2018 & 28.35 & 23.64 & 76.27 & 91.07 & 195.4 \\
\hline Mean & 25.80 & 20.45 & 73.74 & 90.47 & 62.9 \\
\hline \multicolumn{6}{|l|}{ WS18 } \\
\hline Jul 2018 & 28.80 & 25.67 & 84.15 & 93.70 & 182.0 \\
\hline Aug 2018 & 28.01 & 24.97 & 85.65 & 94.92 & 309.6 \\
\hline Sep 2018 & 29.00 & 25.12 & 81.98 & 92.63 & 245.9 \\
\hline Oct 2018 & 27.98 & 23.95 & 81.88 & 94.12 & 197.3 \\
\hline Nov 2018 & 26.54 & 21.16 & 74.72 & 92.37 & 56.2 \\
\hline Mean & 28.06 & 24.17 & 81.68 & 93.55 & 198.2 \\
\hline
\end{tabular}




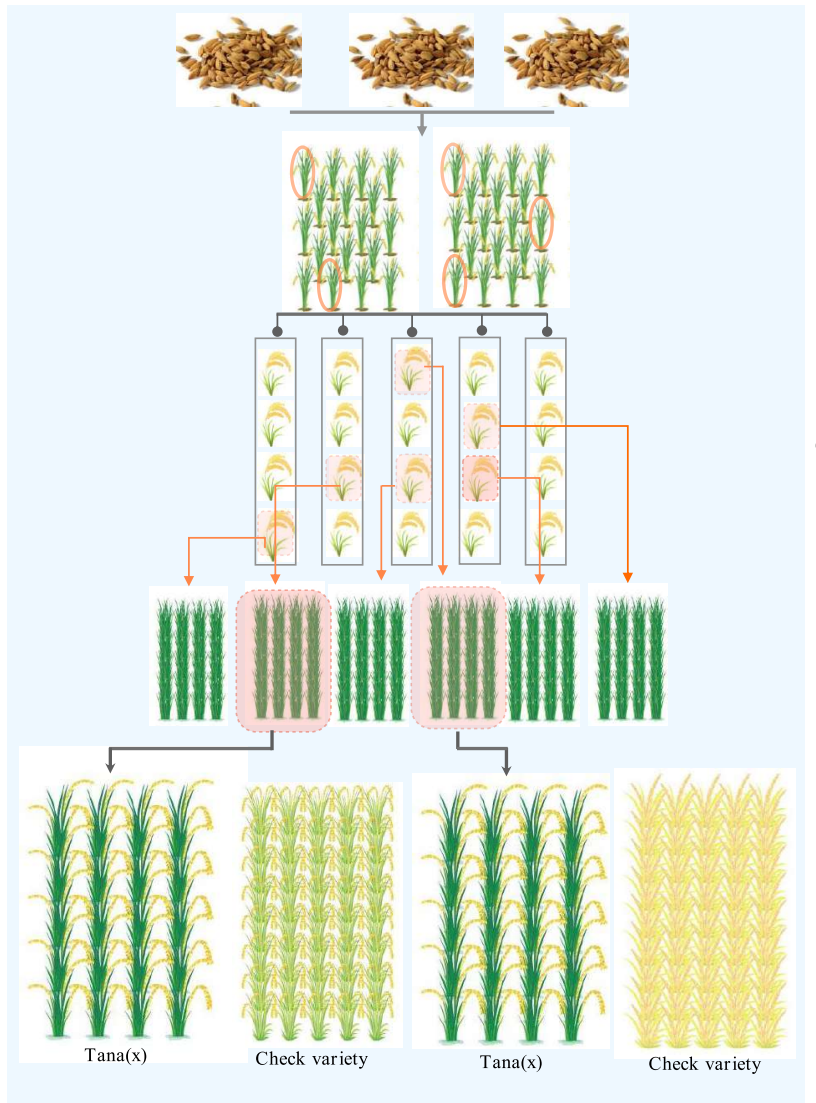

\section{Season \\ Details \\ The sixty DOA2 seeds from each source (total one hundred and eighty seeds) were grown at Tana Grain Co. Ltd. rice research field, Phan, \\ Chiang Rai province. Twenty plants were selected on the basis of their superior and similar phenotype as DOA2}

In the $2^{\text {nd }}$ season, the individual plants were grown separately with proper spacing and evaluated by visual characters. In the $3^{\text {rd }}$ season, the plants were grown as panicle/row with spacing $25 \times 25 \mathrm{~cm}$. The off-type plants in each row were rouged out.

The $4^{\text {th }}$ season was preliminary yield trial. The selected progenies now called candidate lines were grown in replicated trial by using DOA1 and DOA2 as checked varieties. The off-type

plants in each line were rouged out.

$5^{\text {th }}$ and $6^{\text {th }}$ season

The five candidate were grown for yield trial with DOA1 and DOA2, AK, SN and KH. The experiments for yield trial were conducted in (Dec 17 - Oct 18) RCBD with three replications in DS17/18 and WS18. The agronomic traits, cooking quality and sensory test were evaluated.

Fig. S1 Scheme of pure-line selection of DOA2 derived from 3 sources from the 1st-6th seasons in Phan district, Chiang Rai province. 